\title{
REHABILITASI MEDIK PADA PENDERITA DISFAGIA
}

\author{
Jenny J. C. Pandaleke \\ Lidwina S. Sengkey \\ Engeline Angliadi
}

\author{
Program Studi Ilmu Kedokteran Fisik dan Rehabilitasi \\ Fakultas Kedokteran Universitas Sam Ratulangi Manado \\ Email: joan_mdo@yahoo.com
}

\begin{abstract}
Dysphagia is a common symptom in clinical pratice, suffered by all age groups, and associated with multiple systemic disorders, inter alia: diabetes mellitus, hyperthyroidism, lupus erythematosus, dermatomyositis, stroke, as well as Parkinson's and Alzheimer's diseases. The diagnosis of dysphagia is based on anamnesis, physical examination (including examination of the patient during eating or drinking), and supporting examination, such as videofluorographic swallowing study (VFSS) and fiberoptic endoscopic evaluation of swallowing (FEES). The management of dysphagia in the medical rehabilitation field requires a teamwork consisting of a physical therapist, a speech therapist, an occupational therapist, rehabilitation nurses, as well as a nutritionist and several other specialists. The occurence of dysphagia is closely connected with malnutrition, dehydration, respiratory tract infections, duration of hospitalization, and even death. Therefore, early diagnosis and treatment are very important in the management of dysphagia.
\end{abstract}

Keywords: dysphagia, rehabilitation

\begin{abstract}
Abstrak: Disfagia sering ditemukan dalam praktek klinik, dan bisa diderita oleh semua kelompok usia dan berhubungan dengan multiple systemic disorders, antara lain diabetes melitus, hipertiroidisme, lupus eritematosus, dermatomiositis, stroke, serta penyakit Parkinson dan Alzheimer. Diagnosis disfagia ditegakkan melalui anamnesis, pemeriksaan fisik (termasuk pemeriksaan saat penderita makan atau minum), dan pemeriksaan penunjang seperti videofluroskopi dan fiberoptic endoscopic evaluation of swallowing (FEES). Penanganan dalam bidang rehabilitasi medik membutuhkan kerjasama tim yang terdiri dari seorang dokter spesialis kedokteran fisik dan rehabilitasi, ahli terapi bicara, ahli terapi okupasi, perawat rehabilitasi, dan juga membutuhkan kerjasama dengan seorang ahli gizi dan beberapa bidang spesialisasi yang lain. Disfagia sangat berhubungan dengan terjadinya malnutrisi, infeksi saluran pernapasan, dehidrasi, bertambahnya jumlah hari rawat, dan bahkan kematian. Oleh karena itu, diagnosis dan penanganan dini sangat dibutuhkan dalam penatalaksanaan disfagia.
\end{abstract}

Kata kunci: disfagia, rehabilitasi

Disfagia berasal dari bahasa Yunani yaitu dys yang artinya sulit dan phagein yang artinya memakan. Disfagia memiliki banyak definisi tetapi yang sering digunakan adalah kesulitan dalam menggerakan makanan dari mulut ke dalam lambung. 1,2

Disfagia sering ditemukan dalam praktek klinik pada semua kelompok usia dan sering berhubungan dengan multiple systemic disorders (misalnya: diabetes melitus, hipertiroidisme, lupus eritematosus, dermatomiositis, stroke, serta penyakit Parkinson dan Alzheimer). ${ }^{1,3}$

Terdapatnya disfagia dapat mengakibatkan terjadinya malnutrisi, dehidrasi, 
infeksi saluran napas, bertambahnya jumlah hari rawat inap, dan bahkan kematian; oleh sebab itu, diagnosis dan penanganan dini terhadap disfagia sangat penting dilakukan. ${ }^{4-6}$

\section{PROSES MENELAN}

\section{Struktur yang berperan}

Area anatomi yang berhubungan dengan proses menelan meliputi rongga mulut, faring, laring, dan esofagus. Struktur rongga mulut meliputi bibir anterior, gigi, palatum durum, palatum mole, uvula, mandibula, dasar mulut, lidah, dan arkus faringeus. $^{2}$

Lidah sebagian besar disusun oleh serat-serat otot rangka yang dapat bergerak ke segala arah. Sehubungan dengan proses menelan, lidah dibagi menjadi bagian oral dan bagian faringeal. Lidah bagian oral meliputi bagian ujung, depan, tengah, dan belakang daun lidah. Lidah bagian oral aktif selama proses bicara dan proses menelan pada fase oral, dan berada dibawah kontrol kortikal (volunter). Lidah bagian faringeal atau dasar lidah dimulai dari papila sirkumvalata sampai tulang hioid. Dasar lidah aktif selama fase faringeal dan berada dibawah kontrol involunter dengan koordinasi batang otak, tetapi bisa juga berada dibawah kontrol volunter. Atap mulut dibentuk oleh maksila (palatum durum), velum (palatum mole), dan uvula. $^{2}$

Struktur faring yang berperan dalam proses menelan meliputi 3 otot konstriktor faringeal, yaitu superior, medial, dan inferior, yang berorigo pada kranium, tulang hioid, dan kartilago tiroid, serta berinsersio pada bagian posterior median raphe. Otot krikofaringeal merupakan struktur faring yang paling inferior. Kontraksi otot ini akan mencegah masuknya udara ke dalam esofagus saat respirasi. Otot ini melekat pada kartilago krikoid dan bersama dengan lamina krikoid membentuk valvula ke dalam esofagus yang dikenal dengan upper esophageal sphincter (UES) atau pharyngoesophageal sphincter (PES). UES berfungsi mengurangi risiko aliran balik makanan dari esofagus ke faring. Pada waktu tertentu sfingter ini terbuka untuk mengijinkan bolus makanan masuk ke dalam esofagus. ${ }^{2,7}$

Esofagus merupakan lapisan otot berbentuk tabung dengan panjang sekitar 23-25 cm dan mempunyai sfingter pada kedua ujungnya, yaitu UES pada bagian atas dan lower esophagal sphincter (LES) pada bagian bawah. ${ }^{2}$

\section{Fungsi menelan normal}

Proses menelan dibagi menjadi 4 fase yaitu: 1) fase persiapan oral; 2) fase oral; 3) fase faringeal; dan 4) fase esofageal. ${ }^{2,8}$

\section{Fase persiapan oral}

Selama fase persiapan oral makanan dimanipulasi dan dikunyah. Proses mengunyah sendiri merupakan suatu pola siklik berulang dari gerakan rotasi lateral otototot labial dan mandibular. Lidah memosisikan makanan di atas gigi saat gigi atas dan bawah bertemu dan menghancurkan material diatasnya. Makanan akan jatuh ke arah medial menuju lidah dan lidah akan mengembalikan material tersebut ke atas gigi pada saat mandibula dibuka. Selama mengunyah, lidah mencampur makanan dengan saliva. Tekanan dalam otot bukal akan menutup sulkus lateral dan mencegah makanan jatuh ke arah lateral ke dalam sulkus di antara mandibula dan pipi. ${ }^{2,7,8}$

\section{Fase oral}

Fase oral diawali saat lidah memulai pergerakan posterior dari bolus makanan. Selama fase ini lidah mendorong bolus ke arah posterior sampai terjadi pemicuan fase faring. Bagian tengah lidah secara berurutan menekan bolus ke arah posterior melawan palatum durum. Suatu fase oral yang normal membutuhkan otot labial yang intak untuk memastikan penutupan bibir yang sempurna sehingga mencegah makanan keluar dari rongga mulut; pergerakan lidah yang lengkap untuk mendorong bolus ke posterior; otot bukalis 
yang intak untuk memastikan material tidak jatuh ke dalam sulkus lateralis; dan otot palatum yang normal serta kemampuan untuk bernapas secara normal melalui hidung. Oral transit time adalah waktu yang dihitung sejak awal pergerakan lidah untuk memulai fase oral sampai saat bolus head melewati titik antara arkus faringeus anterior dan titik dimana batas bawah mandibula menyilang dasar lidah, dengan nilai normal sekitar 1-1,5 detik. ${ }^{2,8}$

Pada saat lidah bergerak membawa bolus ke arah posterior, reseptor sensorik pada orofaring dan lidah sendiri dirangsang untuk mengirimkan informasi sensorik ke korteks dan batang otak. Selanjutnya, pusat pengenalan sensorik pada medula dalam nukleus traktus solitaris mengidentifikasi stimulus menelan dan mengirimkan informasi ke nukleus ambigus yang kemudian menginisiasi fase faringeal. Pada saat bolus head melewati setiap titik yang terletak antara arkus faringeus bagian anterior dan daerah dimana dasar lidah melintasi tepi bawah mandibula, fase oral berakhir dan fase faringeal dipicu. ${ }^{2,8}$

\section{Fase faringeal}

Fase faringeal dimulai saat terjadi proses pemicuan. Pada fase ini terjadi beberapa aktifitas: 1) elevasi dan retraksi velum serta penutupan sempurna dari port velopharyngeal untuk mencegah masuknya material ke dalam rongga hidung; 2) elevasi dan pergerakan anterior dari hioid dan laring; 3) penutupan laring oleh 3 sfingter untuk mencegah masuknya material ke dalam jalan napas; 4) terbukanya sfingter krikofaringeal untuk memungkinkan masuknya material dari faring ke esofagus; 5) melandainya dasar lidah untuk membawa bolus ke faring diikuti retraksi dasar lidah untuk menyentuh bagian anterior dari bulging posterior dinding faring; dan 6) kontraksi dari atas ke bawah yang progresif dari otototot konstriktor faringeal. Pharyngeal transit time adalah waktu yang dihitung sejak bolus bergerak dari titik dimana fase faringeal dipicu melewati cricopharyngeal juncture ke dalam esofagus,dengan nilai normal 0,35-0,48 detik, dan maksimum bisa sampai 1 detik.

\section{Fase esofageal}

Waktu transit esofageal diukur dari saat bolus memasuki esofagus pada UES, melewatinya, dan masuk ke dalam lambung melalui LES, dengan nilai normal bervariasi 8-20 detik. Gerakan peristaltik yang dimulai pada puncak esofagus mendorong bolus dengan pola berurutan ke arah kaudal sepanjang esofagus sampai LES terbuka dan memungkinkan bolus memasuki lambung. Fase esofageal ini tidak dapat diintervensi dengan terapi latihan atau teknik kompensasi apapun; oleh sebab itu, bila ditemukan kecurigaan adanya gangguan pada fase esofageal, penderita perlu dirujuk ke ahli gastroenterologi sehingga bisa dilakukan pemeriksaan dan penanganan lebih lanjut., ${ }^{2,8,9}$

\section{DISFAGIA}

\section{Penyebab disfagia}

Disfagia dapat terjadi pada satu atau lebih fase menelan dan dapat disebabkan oleh berbagai macam penyebab (Tabel 1). Penderita dengan gangguan neurologik lebih sering mengalami gangguan pada fase oral. $^{8}$

\section{Penilaian disfagia}

Penilaian disfagia dilakukan dengan anamnesis, pemeriksaan fisik, dan pemeriksaan penunjang. ${ }^{9}$

\section{Anamnesis}

Data harus dikumpulkan dari riwayat kesehatan umum penderita. Riwayat neurologik yang mungkin berhubungan dengan beberapa penyakit yang dapat menyebabkan disfagia seperti multiple sclerosis, stroke, serta penyakit Parkinson dan Alzheimer harus ditanyakan. 
Tabel 1. Penyebab disfagia ${ }^{10}$

\begin{tabular}{|c|c|c|}
\hline $\begin{array}{l}\text { Oropharyngeal dysphagia: } \\
\text { Neurologic disease: } \\
\text { - Cerebrovascular } \\
\text { - } \text { accident } \\
\text { - } \text { Parkinson disease } \\
\text { - } \text { Multiple sclerosis } \\
\text { - Alzheimerlasma } \\
\text { Myopathic disease : } \\
\text { - Myositis } \\
\text { - Myasthenia gravis }\end{array}$ & $\begin{array}{l}\text { Metabolic disease: } \\
\bullet \quad \text { Hyperthyroidism } \\
\text { Inflammatory/autoimmune disease } \\
\bullet \quad \text { Amyloidosis } \\
\bullet \quad \text { Sarcodosis } \\
\text { - SLE } \\
\text { Infectious disease: } \\
\text { • Meningitis } \\
\text { • Viral (coxsackie, herpes) } \\
\text { Structural disease }\end{array}$ & $\begin{array}{cl}\text { - } & \text { Congenital webs } \\
\text { - } & \text { Plummer-Vinson } \\
\text { - } & \text { syndrome } \\
\text { - } & \text { Cricoplasma } \\
\text { - } & \text { Zenker divertikulum } \\
\text { - Extrinsic compression } \\
\text { - Poor dentition } \\
\text { Iatrogenic disease: } \\
\text { - Medication side effect } \\
\text { - Surgical resection } \\
\text { - Radiation induced }\end{array}$ \\
\hline $\begin{array}{l}\text { Esofageal Dysphagia: } \\
\text { Neuromuscular disorders: } \\
\text { - Achalasia } \\
\text { - Diffuse esophageal } \\
\text { spasm } \\
\text { Structural lesion (intrinsic): } \\
\text { - Benign peptic stricture } \\
\text { - Esophageal rings and } \\
\text { - } \text { Esobs } \\
\text { - Esophageal diverticula }\end{array}$ & $\begin{array}{l}\text { - Esophageal carcinoma } \\
\text { - } \text { Medication induced stricture } \\
\text { - Eosinophilic esophagitis } \\
\text { Structural lesion (extrinsic): } \\
\text { - Vascular compression } \\
\text { - Mediastinal lesion } \\
\text { - Cervical osteoarthritis }\end{array}$ & \\
\hline
\end{tabular}

Operasi yang pernah dialami penderita pada kepala dan leher juga perlu ditanyakan. Semua pengobatan yang sedang dijalani penderita harus dicatat. Obat-obatan dengan efek samping seperti sedasi, kelemahan otot, dan disorientasi dapat menyebabkan disfagia. Selain itu, faktor psikososial juga dapat memengaruhi proses menelan, terutama pada orangtua. ${ }^{9}$

Keluhan subyektif penderita dapat membantu menegakkan diagnosis disfagia, yaitu antara lain: air liur yang mengalir berlebihan; batuk atau kesedakan saat makan; terkumpulnya makanan pada pipi, di bawah lidah, atau pada palatum durum; suara serak; suara cegukan setelah makan atau minum atau beberapa kali membersihkan kerongkongan; susah mengontrol gerakan lidah; kelemahan otot wajah; harus menelan beberapa kali untuk satu bolus makanan; slurred speech; adanya perasaan makanan seperti tertahan di leher atau dada; dan waktu mengunyah serta waktu makan yang lebih lama. ${ }^{11-13}$

\section{Pemeriksaan fisik}

Pemeriksaan fisik umum sangat penting dilakukan untuk melihat adanya penyakit kardiopulmoner, gastrointestinal, atau neurologik yang dapat memengaruhi fungsi menelan. Pemeriksaan dilakukan juga terhadap status mental, kemampuan bekerjasama, dan fungsi bahasa penderita. Saraf kranialis harus dinilai secara teliti. ${ }^{7,9}$

Pemeriksaan terhadap fungsi pernapasan meliputi tanda-tanda obstruksi atau restriksi seperti takipnea, stridor, penggunaan otot pernapasan tambahan, dan pergerakan dinding dada yang asimetris.,

Inspeksi dan palpasi terhadap kelainan struktur pada kepala dan leher perlu dilakukan. Sensasi pada wajah diperiksa secara bilateral; juga kekuatan otot-otot wajah. Otot maseter dan temporalis dipalpasi saat penderita diminta menggigit atau mengunyah. Pemeriksaan ini dapat dilakukan pada saat pemeriksaan saraf kranialis. $^{9}$ 
Pemeriksaan intraoral dilakukan dengan inspeksi intraoral untuk melihat lesi, sisa makanan, atau kelainan struktural. Palpasi dengan sarung tangan pada dasar mulut, gusi, fosa tonsiler, bahkan lidah, untuk menyingkirkan adanya tumor. Adanya atrofi, kelemahan, dan fasikulasi lidah dicatat. Kekuatan lidah bisa diukur dengan menempatkan jari pada pipi bagian luar dan menahan lidah penderita yang diminta untuk menekan pipi dari dalam.

Palatum diinspeksi untuk melihat posisi simetris pada saat istirahat dan saat fonasi. Setiap sisi palatum distimulasi untuk menimbulkan refleks muntah, sambil memperhatikan apakah palatum mole dan dinding faring berkontraksi secara simetris. Adanya refleks primitif (sucking, biting, dan snout) perlu dicatat. Terdapatnya refleks-refleks ini pada orang dewasa mengindikasikan adanya kerusakan pada kedua hemisfer atau lobus frontalis yang menyebabkan kelemahan oral motor control. $^{9}$

\section{Pemeriksaan penunjang}

Pemeriksaan penunjang yang bisa digunakan untuk mendiagnosis gangguan menelan ialah: videofluorographic swallowing study (VFSS), fiberoptic endoscopic evaluation of swallowing (FEES), dan ultrasonografi.

\section{Videofluorographic swallowing study (VFSS)}

Videofluorographic swallowing study merupakan baku emas untuk mengevaluasi proses menelan. Pada pemeriksaan ini penderita diminta untuk duduk dengan nyaman dan diberikan makanan yang dicampur barium agar tampak radiopak. Saat penderita sedang makan dan minum dilakukan observasi gambaran radiologik pada monitor video dan direkam., 9,15

\section{Fiberoptic endoscopic evaluation of swallowing (FEES)}

FEES merupakan suatu laringoskop transnasal yang dapat digunakan untuk mengevaluasi fungsi laring, menilai jumlah residu hipofaringeal, dan mengobservasi ada tidaknya aspirasi. Endoskop dimasukan melalui hidung melewati nasofaring dan ditempatkan di dalam laringofaring di atas pita suara palsu. Bolus berbentuk cair dan padat diberi warna hijau sehingga mudah dilihat. $^{1,16}$

\section{Ultrasonografi}

Ultrasonografi digunakan untuk menilai fungsi oral saja, yaitu fungsi lidah dan oral transit time; juga gerakan tulang hioid. Metode ini merupakan suatu pemeriksaan yang noninvasif dan hanya menggunakan cairan dan makanan biasa. ${ }^{1,2}$

\section{PENANGANAN REHABILITASI PADA PENDERITA DISFAGIA}

Terdapat beberapa cara penanganan rehabilitasi penderita disfagia, yaitu: teknik postural, modifikasi volume dan kecepatan pemberian makanan, modifikasi diet, compensatory swallowing maneuver, teknik untuk memperbaiki oral sensory awareness, stimulasi elektrik, terapi latihan, dan penyesuaian peralatan yang digunakan.

\section{Teknik postural}

Beberapa penelitian mengungkapkan bahwa perubahan postur kepala dan tubuh dapat mengeliminasi terjadinya aspirasi pada penderita disfagia. Sebaiknya terapis harus mengetahui secara tepat gangguan anatomi dan fisiologik yang dialami penderita sebelum menentukan postur yang tepat. Beberapa teknik postural yang digunakan yaitu: chin down atau chin tuck, chin up, head rotation, head tilt, dan lying down. ${ }^{2}$

\section{Modifikasi volume dan kecepatan pemberian makanan}

Pada penderita dengan keterlambatan dalam pemicuan fase faringeal, bolus yang besar akan membantu terjadinya triggering. Pada penderita yang mengalami gangguan fase faringeal sendiri membutuhkan 2-3 
kali menelan untuk setiap bolus. Pemberian makanan dalam jumlah terlalu banyak dan terlalu cepat akan menyebabkan terkumpulnya bolus di dalam laring dan menyebabkan aspirasi sedangkan pemberian makanan dalam jumlah sedikit dan secara lambat akan mengurangi terjadinya aspirasi. $^{2}$

\section{Modifikasi diet}

Modifikasi tekstur bolus sangat diperlukan untuk mencegah terjadinya aspirasi. Makanan dengan konsistensi cair lebih sulit dikontrol dan lebih mudah menyebabkan aspirasi karena dapat mengalir langsung ke dalam faring sebelum terjadinya refleks menelan. Bolus yang lebih kental atau makanan padat lunak lebih aman karena kemungkinan untuk masuk dalam pintu laring lebih kecil. Selain itu, bolus yang lebih kental meningkatkan pergerakan lidah dan membantu mempercepat terjadinya inisiasi fase faringeal. ${ }^{2,17}$

Rekomendasi lain yaitu makanan dalam jumlah sedikit dengan frekuensi pemberian lebih sering dan mengandung tinggi kalori dan tinggi protein. Makanan diberikan dalam jumlah sedikit, $1 / 2$ sampai 1 sendok teh setiap kali menelan. Penderita juga diminta untuk tidak makan sambil berbicara. Bila menggunakan makanan kental, makanan dengan kekentalan seperti madu yang dapat dijadikan pilihan. ${ }^{18}$

\section{Compensatory swallowing maneuver}

Manuver menelan dirancang untuk menempatkan bagian tertentu dari proses menelan normal dibawah kontrol volunter yang meliputi: 2,19

- Effortful swallow: bertujuan memperbaiki gerakan dasar lidah ke arah posterior selama fase faringeal. Penderita diminta untuk menelan dengan menggerakan lidah ke arah posterior secara kuat untuk membantu perjalanan bolus melewati rongga faring.

- Supraglotic swallow: bertujuan menutup pita suara sebelum dan selama proses menelan sehingga melindungi trakea dari aspirasi. Makanan atau minuman di tempatkan dalam mulut, penderita diminta untuk menarik napas dalam kemudian ditahan, lalu penderita menelan 1-2 kali sambil tetap menahan napas, dan batuk dengan segera setelah menelan.

- Super-supraglotic swallow: dirancang untuk menutup pintu masuk jalan napas secara volunter dengan mengangkat kartilago aritenoid ke anterior, ke bagian dasar dari epiglotis sebelum dan selama proses menelan serta menutup erat pita suara palsu.

- Mandehlson maneuever: penderita diminta untuk merasakan adanya sesuatu bergerak pada bagian dalam lehernya saat menelan, kemudian melakukan proses menelan kembali (menggunakan dry swallow atau dengan $1 \mathrm{ml}$ air) tetapi diminta untuk menahan gerakan tadi selama 3-5 detik, kemudian menelan dan rileks.

\section{Teknik untuk memperbaiki oral sensory awareness}

Terdapat beberapa jenis teknik yang meliputi: ${ }^{2,19,20}$

1. Menekan sendok ke arah bawah melawan lidah saat pemberian makanan ke dalam mulut.

2. Memberikan bolus dengan karakteristik sensorik tertentu, seperti bolus dingin, bolus dengan tekstur tertentu, atau bolus dengan rasa yang kuat seperti jus lemon

3. Memberikan bolus yang harus dikunyah sehingga proses mengunyah tersebut akan memberikan stimulasi oral.

4. Memberikan volume bolus yang besar.

5. Thermal tactile stimulation (TTS) dengan melakukan gerakan stroking pada arkus faringeus anterior. Stroking dilakukan menggunakan kaca laring berukuran 00 (telah dimasukan dalan es selama \pm 10 detik) pada arkus faringeus 
anterior dari bagian dasar ke arah atas sejauh yang bisa dijangkau. Terapi ini diangap bisa memberikan stimulus sensorik ke batang otak dan korteks sehingga saat penderita sudah mulai fase oral, maka fase faringeal akan terpicu lebih cepat.

\section{Stimulasi elektrikal}

Neuromuscular electrical stimulation (NMES) bekerja dengan memberikan stimulasi listrik pada otot-otot menelan lewat elektroda yang ditempatkan di atas otot-otot tersebut. Beberapa studi tentang penggunaan stimulasi listrik ini menunjukkan bahwa NMES merupakan alternatif terapi yang efektif dan aman untuk penderita disfagia serta dapat digunakan pada anak-anak. Penggunaan NMES ini efektif pada disfagia akibat penyakit tertentu seperti stroke, kanker pada kepala dan leher, serta multipel sklerosis. $^{20,21}$

\section{Terapi latihan}

Terapi latihan digunakan untuk menguatkan otot-otot, meningkatkan lingkup gerak sendi (LGS) dan koordinasi dari mulut, rahang, bibir, lidah, palatum, dan pita suara. Terapi latihan yang biasanya digunakan antara lain: latihan LGS rahang, latihan penguatan otot lidah, latihan adduksi pita suara, dan latihan metode Shaker. ${ }^{8,19}$

\section{Penyesuaian peralatan yang digunakan}

Beberapa peralatan telah dibuat untuk membantu penderita disfagia, termasuk penderita yang juga mengalami kelemahan ekstremitas atas yang akan memengaruhi kemandirian penderita untuk makan. Peralatan tersebut misalnya gelas dengan sedotan, nose cutout cup, plate guard, sedotan, serta garpu dan sendok yang dimodifikasi. $^{8,22}$

\section{KOMPLIKASI DISFAGIA}

Komplikasi disfagia dapat berupa aspirasi pneumonia, malnutrisi, dehidrasi, obstruksi jalan napas bila bolus berukuran cukup besar yang memasuki jalan napas, dan kematian. ${ }^{2,19}$

\section{PROGNOSIS}

Gangguan menelan yang diakibatkan oleh stroke atau traumatic brain injury memiliki potensi untuk pulih. Mann et al. mendapatkan bahwa sekitar $87 \%$ penderita stroke kembali ke diet semula setelah 6 bulan, tetapi hasil videofluroskopi menunjukkan terdapat $51 \%$ penderita yang tetap menunjukkan adanya gangguan pada proses menelan. Penderita dengan kondisi yang statis atau progresif seperti amyothropic lateral sclerosis, multipel sklerosis, muskular distrofik, dan Parkinsonisme harus dievaluasi secara periodik, dengan mempertimbangkann pemberian nonoral feeding. ${ }^{8,23}$

\section{SIMPULAN}

Diagnosis dan penanganan dini penderita disfagia sangat diperlukan. Penanganan disfagia dalam bidang rehabilitasi medik bertujuan untuk mempertahankan asupan nutrisi yang adekuat dan memaksimalkan proteksi terhadap jalan napas; dalam hal ini sangat diperlukan kerjasama tim rehabilitasi dengan bidang spesialisasi lainnya.

\section{DAFTAR PUSTAKA}

1. Skavaria AM, Schroeder-lopez RA. Dysphagia Management. In: Gillen G, Burkhard A, editors. Stroke Rehabilitation: A Functional Based Approach. St Louis: Mosby, 1998; p. 407-22.

2. Longemann JA. Evaluation and Treatment of Swallowing Disorder (Second Edition). Austin: Pro-ed, 1998.

3. Fass R, Gasiorowska A. Current approach to dysphagia. Gastroenterology and Hepatology Journal. 2009;5:269-79.

4. Falsetti P, Acciai C, Palilla R, Bosi M, Carpinteri F, Zingarelli A, et al. Oropharyngeal dysphagia after stroke: 
Incidence, diagnosis and clinical predictor in patients admitted to neurorehabilitation unit. Journal of Stroke and Cerebrovascular Disease. 2009;18:329-35.

5. Martino R, Foley N, Bhogal S, Diamant N, Speechley M, Teasell R. Dysphagia after stroke incidence, diagnosis and pulmonary complication. Stroke. 2005;36:2756-63.

6. Hamiddon BB. Risk factors and outcome of dysphagia after an acute ischaemic stroke. Med J Malaysia. 2006;61:55357.

7. Palmer JB, Pelletier CA, Matsuo K. Rehabilitation of patient with swallowing disorder. In: Braddom RL, editor. Physical Medicine and Rehabilitation. Philadelphia: Elsevier Saunders, 2007; p. 581-600.

8. Zorowitz RD. Speech therapy and disorder of deglutition. In: Lazar RB, editor. Principles of Neurologic Rehabilitation. Chicago: Mc Graw-Hill, 1997; p. 491511.

9. Miller RM, Groher M, Yorkston KM, Rees TS, Palmer JB. Speech, language, swallowing and auditory rehabilitation. In: Delisa JA, Gans BM, Walsh NE. editors. Physical Medicine and Rehabilitation, Principle and Practise, Volume 1 (Fourth Edition). Philadelphia: Lippincot Williams and Wilkins, 2005; p. 1025-50.

10. Prasad GA. Clinical approach to a patient with dysphagia. Medicine update. Available from: http://www.apiindia.org/pdf/medicine_ update_2007/63.pdf

11. Caplan LR. What Remain After Stroke. In: Stroke. St. Paul: AAN Press, 2005; p. 139-54.

12. Finestone HM, Greene-Finestone LS. Rehabilitation Medicine: 2. Diagnosis of dysphagia and its nutritional management of stroke patients. CMAJ. 2003;169(10): 1041-4.

13. Hardy E. Bedside evaluation of dysphagia. Imaginart International. 1995;1:33-34.

14. Ramsey DJC, Smithard DG, Kalra L. Early assesment of dysphagia and aspiration risk in acute stroke patient. Stroke. 2003;34:1252-7.

15. Pikus L, Levine MS, Yang YX, Rubesin SE, Katzka DA, Laufer I, et al. Videofluoroscopic studies of swallowing dysfunction and the relative risk of pneumonia. AJR. 2003;180:1613-6.

16. Warnacke T, Teismann I, Meimann W, Olenberg S, Zimmermann J, Kramer C. Assesment of aspiration risk in acute ischaemic stroke. Evaluation of simple swallowing provocation test. $\mathrm{J}$ Neurol Neurosurg Psychiatry. 2008;79:312-4.

17. Tsukada T, Taniguchi $H$, Ootaki S, Yamada Y, Inoue M. Effect of food texture and head posture on oropharyngeal swallowing. J Appl Physiol. 2009;106:1848-57.

18. Nutritional Guidelines For Symptom Management: Dysphagia. BC Cancer Agency Care and Research. Available from:

http://www.bccancer.bc.ca/NR/rdonlyre s/5C9BA6AE-C7EC-40FA-AAEF2B81AA26BEE5/56309/Dysphagia.pdf

19. Tan J. Practical Manual of Physical Medicine and Rehabilitation. St Louis: Mosby, 1998:515-37

20. Lim KB, Lee HJ, Lim SS, Choi YI. Neuromuscular electrical stimulation and thermal tactile stimulation for dysphagia caused by stroke. J Rehabil Med.2009;41:174-8.

21. Wijting Y. Neuromuscular Electrical Stimulation The Treatment of Dysphagia : a Summary of the Evidence. St. Paul: Empi Recovery Science, 2009.

22. Jelm JM. Treatment of feeding and swallowing disorders in children: An overview. In: Cherney LR, editor. Clinical Management of Dysphagia in Adults and Children (Second Edition). Maryland: Aspen Publisher, 1994; p. 185-98.

23. Mann G, Hankey GJ, Cameron D. Swallowing function after stroke: Prognosis and prognostic factors at 6 months. Stroke. 1999;30;744-8. 